Bul. Agrohorti 3 (3) : 366 - 376 (2015)

\title{
Pengujian Vigor Daya Simpan dengan Metode Pengusangan Cepat Fisik dan Vigor Kekuatan Tumbuh pada Benih Padi
}

\author{
Testing Seed Storability with Physical Rapid Aging Method and Vigor on Rice Genotypes \\ Cutrisni, Faiza C. Suwarno* dan Suwarno
}

Departemen Agronomi dan Hortikultura, Fakultas Pertanian, Institut Pertanian Bogor

(Bogor Agricultural University), Jl. Meranti, Kampus IPB Darmaga, Bogor 16680, Indonesia

Telp.\&Faks. 62-251-8629353 e-mail agronipb@indo.net.id

*Penulis untuk korespondensi : faizacsuwarno@yahoo.co.id

Disetujui 14 November 2015 /Published online 12 Desember 2015

\begin{abstract}
The objectives of the study were to evaluate seed storability and vigor of upland, lowland and swampy rice genotypes. Preliminary experiment indicated that the appropriate duration of rapid aging with $40-45^{\circ} \mathrm{C}$ and $100 \%$ RH, for testing seed storability $\left(V_{D S}\right)$ were 40, 60, and 48 hours for lowland, upland, and swampy rice seeds respectively. The appropriate methods for testing vigor to drought were UKDdp using strawpaper treated

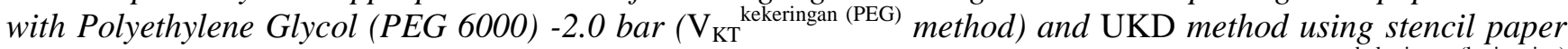
placed on $2 \mathrm{~cm}$ depth standing water, where the seed located at $30 \mathrm{~cm}$ above water surface $\left(\mathrm{V}_{\mathrm{KT}}^{\text {kekeringan (ketinggian) }}\right.$ method). $\mathrm{V}_{\mathrm{KT}}$ kekeringan (ketinggian) method was the best one since the method was simpler and cheaper than the other. The appropriate method for testing vigor to salinity was UKDdp using strawpaper treated with $4000 \mathrm{ppm} \mathrm{NaCl}$ $\left(\mathrm{V}_{\mathrm{Kt}}^{\text {salin }(\mathrm{NaCl})}\right)$. Rice seed consisting of 10 lowland, 20 upland, and 20 swampy. There were no significant coeficient correlation among storability, vigor to drought and vigor to salinity. Genotype with highest storability were B12539-7-SI-1-1-MR-2-PN-3-1, B12154D-MR-22-8, and B13109-5-MR-3-KA-1 for lowland, upland, and swampy respectively. Genotipes with the highest vigor to drought were Sintanur and B12653-MR-8-2-PN-3-1 for lowland, B12154D-MR-22-8 for upland rice, whereas genotype with the highest vigor to salinity for swampy rice was B13120-19-MR-2-KA-1.
\end{abstract}

Keyword: rapid aging, vigor, rice genotypes, Oryza sativa L.

\section{ABSTRAK}

Tujuan dari penelitian ini adalah untuk mengevaluasi daya simpan dan vigor benih dari dataran tinggi, dataran rendah dan genotipe padi rawa. Percobaan pendahuluan menunjukkan bahwa durasi yang sesuai untuk pengusangan cepat adalah $40-45^{\circ} \mathrm{C}$ dan $100 \% \mathrm{RH}$, pengujian untuk daya simpan $\left(V_{D S}\right)$ adalah 40, 60, dan 48 jam untuk dataran rendah, dataran tinggi, dan benih padi rawa. Metode yang tepat untuk menguji vigor kekeringan yaitu UKDdp menggunakan kertas merang dan diberikan Polyethylene Glycol (PEG 6000) -2.0 bar (Metode $\mathrm{V}_{\mathrm{KT}}{ }^{\text {kekeringan (PEG) }}$ ) dan metode UKD menggunakan kertas stensil ditempatkan pada $2 \mathrm{~cm}$ di kedalaman air dengan posisi berdiri, di mana benih yang terletak di $30 \mathrm{~cm}$ di atas permukaan air (Metode $\mathrm{V}_{\mathrm{KT}}{ }^{\text {kekeringan }}$ (ketinggian) $). \mathrm{V}_{\mathrm{KT}}$ kekeringan (ketinggian) merupakan metode yang terbaik karena lebih sederhana dan lebih murah. Metode yang tepat untuk menguji vigor salinitas adalah UKDdp menggunakan kertas merang dengan $4000 \mathrm{ppm} \mathrm{NaCl}$ $\left(\mathrm{V}_{\mathrm{Kt}}^{\text {salin }(\mathrm{NaCl})}\right)$. Benih terdiri dari 10 dataran rendah, 20 dataran tinggi, dan 20 rawa. Tidak ada koefisien korelasi yang signifikan antara daya simpan, vigor kekeringan dan vigor salinitas. Genotipe dengan daya simpan tertinggi yang masing-masing B12539-7-SI-1-1-MR-2-PN-3-1, B12154D-MR-22-8, dan B13109-5-MR-3-KA-1 untuk dataran rendah, dataran tinggi, dan Sebaran. Genotipes dengan vigor kekeringan tertinggi adalah Sintanur dan B12653-MR-8-2-PN-3-1 untuk dataran rendah, B12154D-MR-22-8 untuk padi gogo, sedangkan genotipe dengan vigor salinitas tertinggi padi rawa adalah B13120 -19-MR-2-KA-1.

Kata kunci : genotipe padi, Oryza sativa L., pengusangan cepat, vigor 


\section{PENDAHULUAN}

Salah satu upaya mendukung penyediaan pangan nasional, yaitu dengan mengembangkan dan memanfaatkan lahan non-irigasi seperti lahan kering dan lahan rawa. Ketersediaan benih bermutu dalam jumlah dan waktu yang tepat perlu diusahakan agar kebutuhannya terpenuhi. Pengujian benih dilakukan untuk menentukan baik mutu fisik maupun mutu fisiologi suatu jenis atau kelompok benih (Sutopo, 2004).

Pengujian vigor benih sangat diperlukan dalam informasi mutu benih. Vigor adalah kemampuan benih untuk tumbuh normal pada keadaan lingkungan sub-optimum (Sutopo, 2004). Parameter vigor benih $\left(\mathrm{V}_{\mathrm{g}}\right)$ yaitu Vigor Daya Simpan $\left(\mathrm{V}_{\mathrm{DS}}\right)$ dan Vigor Kekuatan Tumbuh $\left(\mathrm{V}_{\mathrm{KT}}\right)$. $\mathrm{V}_{\mathrm{DS}}$ yaitu parameter viabilitas lot benih yang menunjukkan vigor benih pada kurun waktu periode II atau periode simpan sedangkan $\mathrm{V}_{\mathrm{KT}}$ merupakan parameter vigor lot benih yang menunjukkan kemampuan benih tumbuh normal pada kondisi lapang yang sub-optimum (Sadjad, 1994).

Pengujian vigor benih sangat diperlukan dalam informasi mutu benih. Vigor adalah kemampuan benih untuk tumbuh normal pada keadaan lingkungan sub-optimum (Sutopo, 2004). Parameter vigor benih $\left(\mathrm{V}_{\mathrm{g}}\right)$ yaitu Vigor Daya Simpan $\left(\mathrm{V}_{\mathrm{DS}}\right)$ dan Vigor Kekuatan Tumbuh $\left(\mathrm{V}_{\mathrm{KT}}\right)$. $\mathrm{V}_{\mathrm{DS}}$ yaitu parameter viabilitas lot benih yang menunjukkan vigor benih pada kurun waktu periode II atau periode simpan sedangkan $\mathrm{V}_{\mathrm{KT}}$ merupakan parameter vigor lot benih yang menunjukkan kemampuan benih tumbuh normal pada kondisi lapang yang sub-optimum (Sadjad, 1994). Penelitian ini bertujuan untuk mendapatkan metode pengusangan cepat yang terbaik dan mudah dilakukan pada pengujian vigor benih padi sawah, padi gogo dan padi rawa. Tujuan lainnya yaitu untuk mempelajari korelasi antara $\mathrm{V}_{\mathrm{DS}}$ dan $\mathrm{V}_{\mathrm{KT}}$ benih padi sawah, padi gogo dan padi rawa.

\section{BAHAN DAN METODE}

Penelitian ini dilaksanakan di Laboratorium Ilmu dan Teknologi Benih. Departemen Agronomi dan Hortikultura, Fakultas Pertanian, Institut Pertanian Bogor, Penelitian dimulai bulan April sampai Agustus 2011.

Bahan yang digunakan adalah benih padi yang berasal dari Balai Besar Penelitian Tanaman Padi Instalasi Muara. Benih yang digunakan dalam percobaan pendahuluan yaitu benih padi sawah, padi gogo, dan padi rawa masing-masing lima genotipe. Percobaan selanjutnya menggunakan 50 genotipe terdiri dari 10 genotipe padi sawah, 20 genotipe padi gogo, dan 20 genotipe padi rawa. Bahan lain yang digunakan dalam penelitian ini adalah kertas merang, kertas stensil daur ulang/koran, plastik, NaCl, PEG-6000 (Polyethylene Glycol), air, aquades, kertas label, amplop dan selotip. Alat-alat yang digunakan, yaitu mesin pengusangan cepat fisik, alat pengepres kertas tipe IPB 75-1, alat pengecambah benih (APB) tipe IPB 73-2A/B, oven, desikator, kain strimin, kain handuk, timbangan analitik, pinset, gelas ukur, hand sprayer, bak rendam, benang kasur, dan penggaris.

\section{Percobaan Pendahuluan}

Percobaan pendahuluan bertujuan untuk mendapatkan lamanya waktu pengusangan pada Metode Pengusangan Cepat (MPC) fisik, dan mendapatkan tingkat konsentrasi PEG-6000 dan $\mathrm{NaCl}$ pada metode kekeringan dan salinitas, serta mendapatkan jumlah kertas dan ketinggian air yang dapat mensimulasi cekaman kekeringan pada perlakuan tingkat kekeringan. Waktu MPC fisik yang digunakan dalam percobaan pendahuluan adalah 0, 24, 48, 72, 96, 120, dan 144 jam. Percobaan tekanan osmotik PEG-6000 pada benih padi gogo terdiri dari $-1.5,-2.0$, dan -2.5 bar dan tingkat salinitas pada benih padi rawa dengan konsentrasi 3000, 4000, dan 5000 ppm NaCl. Jumlah kertas yang digunakan pada perlakuan tingkat kekeringan, yaitu 1-1, 1-2, dan 2-2 lembar.

Rancangan percobaan yang digunakan adalah Rancangan Kelompok Lengkap Teracak (RKLT) dengan satu faktor, yaitu konsentrasi PEG6000, konsentrasi $\mathrm{NaCl}$, dan jumlah kertas. Penentuan lamanya waktu pengusangan menggunakan model regresi kuadratik. Peubah yang diamati pada percobaan pendahuluan hanya daya berkecambah (DB). Perlakuan diulang sebanyak empat ulangan, setiap ulangan menggunakan 25 butir benih. Perlakuan tingkat kekeringan diulang sebanyak tiga ulangan, setiap satuan percobaan menggunakan 15 butir benih.

\section{Percobaan Utama}

Penelitian ini terdiri dari dua percobaan, yaitu pengujian vigor daya simpan benih melalui MPC secara fisik $\left(\mathrm{V}_{\mathrm{DS}}^{\text {fis }}\right)$, dan vigor kekuatan tumbuh $\left(\mathrm{V}_{\mathrm{KT}}\right)$ benih pada kondisi sub-optimum (cekaman kekeringan dan salinitas), yang 
diaplikasikan kepada 10 genotipe padi sawah, 20 genotipe padi gogo, dan 20 genotipe padi rawa. Rancangan yang digunakan pada masing-masing percobaan adalah RKLT dengan satu faktor yaitu genotipe padi. Setiap genotipe diulang tiga kali, dengan menggunakan benih 25 butir/genotipe kecuali pada metode $\mathrm{V}_{\mathrm{KT}}$ kekeringan (ketinggian). Model linier yang digunakan pada setiap percobaan adalah

Keterangan :

$$
Y i j=\mu+\tau i+\beta j+\varepsilon i j
$$

Yij = Pengamatan pada perlakuan genotipe padi ke-i dan kelompok $\mathrm{k}$.

$\mu \quad=$ Rataan umum

$\tau \mathrm{i} \quad=$ Pengaruh perlakuan genotipe padi ke-i $(\mathrm{i}=$ $1,2,3, \ldots . .50)$.

$\mathrm{Bj} \quad=$ Pengaruh kelompok ke-j $(\mathrm{j}=1,2,3)$.

Eij = Pengaruh acak pada perlakuan ke-I dan kelompok ke-j.

Uji lanjut yang digunakan terhadap hasil yang berpengaruh nyata pada penelitian ini adalah Duncans Multiple Test (DMRT) pada taraf nyata 5\% (Gomez dan Gomez, 1995). Selanjutnya dilakukan analisis korelasi antara $\mathrm{V}_{\mathrm{DS}}$ dan $\mathrm{V}_{\mathrm{KT}}$ yang bertujuan untuk mengetahui keeratan hubungan antara $\mathrm{V}_{\mathrm{DS}}$ dengan $\mathrm{V}_{\mathrm{KT}}{ }^{\text {kekeringan }}(\mathrm{PEG})$, ${ }_{\mathrm{vKT}}$ kekeringan (ketinggian), dan VKTSalin $(\mathrm{NaCl})$

Pengujian Vigor Daya Simpan $\left(V_{D S}\right)$ menggunakan Metode Pengusangan Cepat (MPC) Fisik

Percobaan ini bertujuan untuk mengetahui $\mathrm{V}_{\mathrm{DS}}$ dengan menggunakan metode pengusangan cepat fisik. Lama penderaan yang digunakan merupakan hasil dari percobaan pendahuluan berturut-turut untuk genotipe padi sawah, padi gogo, dan padi rawa adalah diusangkan selama 40,61 , dan 48 jam. Posisi benih dalam mesin pengusangan cepat diletakkan pada rak bagian atas.

\section{Pengujian Vigor Kekuatan Tumbuh $\left(V_{K T}\right)$ Benih pada Kondisi Sub-optimum}

Percobaan ini bertujuan untuk mengetahui $\mathrm{V}_{\mathrm{KT}}$ cekaman kekeringan pada genotipe padi sawah dan padi gogo serta cekaman salinitas pada genotipe padi rawa. Metode cekaman kekeringan yang terpilih yaitu menggunakan tekanan osmotik PEG$6000-2$ bar $\left(\mathrm{V}_{\mathrm{KT}}{ }_{\text {kekeringan (PEG) }}\right)$ dan metode tingkat ketinggian $\left(\mathrm{V}_{\mathrm{KT}}{ }_{\text {kekeringan(ketinggian) }}\right)$ jumlah kertas yang digunakan 1-1 lembar dengan posisi benih ditanam pada ketinggian $30 \mathrm{~cm}$ dan diletakkan dalam bak berisi air setinggi $2 \mathrm{~cm}$, sedangkan pada cekaman salinitas konsentrasi yang digunakan adalah $\mathrm{NaCl}$ $4000 \mathrm{ppm} \quad\left(\mathrm{V}_{\mathrm{KT}}{ }^{\text {salin(NaCl)}}\right)$. Dari masing-masing metode $\mathrm{V}_{\mathrm{KT}}$ kekeringan (PEG) dan $\mathrm{V}_{\mathrm{KT}}$ kekeringan(ketinggian), diperoleh 90 satuan percobaan, sedangkan pada metode $\mathrm{V}_{\mathrm{KT}}{ }^{\text {salin( }(\mathrm{NaCl})}$ sebanyak 60 satuan percobaan.

\section{Pelaksanaan Percobaan}

Pengujian viabilitas awal benih ini dimulai dengan melembabkan substrat kertas merang berukuran $10 \mathrm{~cm}$ x $30 \mathrm{~cm}$ dengan merendam dalam air kemudian dipres menggunakan alat pengepres kertas IPB 75-1 sampai airnya tidak menetes. Metode pengecambahan yang digunakan yaitu metode Uji Kertas Digulung didirikan dalam plastik (UKDdp).

\section{Pengujian Vigor Daya Simpan $\left(V_{D S}\right)$ menggunakan Metode Pengusangan Cepat (MPC) Fisik}

Benih dikemas dalam kantong kain strimin kemudian dimasukkan ke dalam mesin pengusangan cepat fisik pada suhu $40-45^{\circ} \mathrm{C}$ dan RH $100 \%$. Benih yang telah didera, selanjutnya dikecambahkan pada alat pengecambah benih IPB 73-2A/B. Metode pengecambahan yang digunakan adalah metode UKDdp dengan substrat kertas merang.

\section{Pengujian Vigor Kekuatan Tumbuh $\left(V_{K T}\right)$ Benih pada Kondisi Sub-optimum}

Pengujian Vigor Kekuatan Tumbuh $\left(\mathrm{V}_{\mathrm{KT}}\right)$ Benih pada Kondisi Sub-optimum Kekeringan. Pada pengujian $\mathrm{V}_{\mathrm{KT}}$ kekeringan (PEG) media tanam subtrat kertas merang dilembabkan menggunakan larutan PEG-6000 dengan cara dioleskan sampai meresap menggunakan kuas. Metode pengecambahan yang digunakan adalah metode UKDdp. Percobaan pendahuluan menggunakan PEG-6000 dengan tiga tingkat tekanan osmotik yaitu -1.5, -2.0, dan -2.5 bar. Berdasarkan hasil percobaan pendahuluan dipilih konsentrasi -2 bar untuk digunakan dalam percobaan utama.

Pada pengujian $\mathrm{V}_{\mathrm{KT}}{ }^{\text {kekeringan (ketinggian) }}$, benih ditanam pada kertas stensil daur ulang dengan jumlah kertas 1-1, 1-2, dan 2-2 lembar tanpa dilembabkan terlebih dahulu. Posisi benih berada pada ketinggian $30 \mathrm{~cm}$ dari permukaan kertas. Metode perkecambahan yang digunakan adalah metode Uji Kertas Digulung (UKD). Benih yang telah digulung diletakkan pada bak rendam yang diisi air setinggi $3 \mathrm{~cm}$. 
Persentase daya berkecambah dari semua

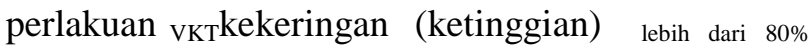
dan secara visual tidak menggambarkan adanya gejala cekaman kekeringan. Berdasarkan hasil percobaan tersebut maka dilakukan pengujian lanjut dengan mengurangi ketinggian air dalam bak menjadi $2 \mathrm{~cm}$ dengan jumlah kertas 1-1 lembar. Pengujian lanjut ini merupakan metode terpilih karena menunjukkan penurunan daya berkecambah yang signifikan sudah mengalami gejala tercekam.

Pengujian Vigor Kekuatan Tumbuh $\left(\mathrm{V}_{\mathrm{KT}}\right)$ Benih pada Kondisi Sub-optimum Salinitas. Pengujian $\mathrm{V}_{\mathrm{KT}}$ pada kondisi salinitas $\left(\mathrm{V}_{\mathrm{KT}}{ }^{\text {salin( }(\mathrm{NaCl})}\right)$, media subtrat kertas merang direndam dalam larutan $\mathrm{NaCl}$ pada konsentrasi 3000, 4000, dan 5000 ppm dalam percobaan pendahuluan, sedangkan pada percobaan utama hanya dengan konsentrasi $\mathrm{NaCl}$ $4000 \mathrm{ppm}$. Media yang telah direndam kemudian dipres dengan alat pengepres kertas sampai air tidak menetes lagi dan benih ditanam dengan metode UKDdp.

\section{Pengamatan}

Pengamatan yang dilakukan dalam penelitian pengujian $\mathrm{V}_{\mathrm{DS}}$ dan $\mathrm{V}_{\mathrm{KT}}$ ini, meliputi tolok ukur daya berkecambah (DB), indeks vigor (IV) benih, berat kering kecambah normal (BKKN). Untuk pengamatan yang dilakukan pada pengujian vigor benih pada kondisi suboptimum salinitas dan kekeringan, ditambahkan peubah lainnya yaitu panjang kecambah (PK), panjang plumula (PP), dan panjang akar (PA). Setiap percobaan pengamatan dilakukan pada hari ke-5 dan ke-7 setelah pengecambahan, kecuali pada percobaan $\mathrm{V}_{\mathrm{KT}}$ kekeringan(ketinggian) pengamatan hanya pada hari ke7.

\section{HASIL DAN PEMBAHASAN}

\section{Percobaan Pendahuluan}

Benih yang digunakan memiliki viabilitas awal $\geq 80 \%$, nilai tengah viabilitas awal pada benih padi sawah, padi gogo dan padi rawa adalah $91 \%$, $91 \%$, dan $88.4 \%$. Salah satu faktor penentu dalam pemilihan MPC adalah kecepatan penurunan persentase daya berkecambah. Penurunan nilai daya berkecambah dibatasi sampai kecepatan penurunan viabilitas $\mathrm{P}_{40}$. Hal ini mengacu pada Sadjad et al. (1999), perish (mati) $40 \%\left(\mathrm{P}_{40}\right)$ adalah lamanya penurunan daya berkecambah benih sampai menjadi $60 \%$.
Penentuan lama pengusangan pada MPC fisik dalam penelitian ini berdasarkan analisis regresi, dari data rata-rata daya berkecambah benih masing-masing varietas jenis padi. Setelah dianalisis persamaan yang terpilih adalah regresi kuadratik. Model dari regresi kuadratik (Gomez dan Gomez, 1995) adalah:

$$
\mathbf{Y}=\mathbf{a}+\mathbf{b}_{1} \mathbf{X}+\mathbf{b}_{2} \mathbf{X}^{2}
$$

dimana $\mathrm{Y}=$ viabilitas benih dan $\mathrm{X}=$ waktu pengusangan.

Persamaan regresi kuadratik pada benih padi sawah dan padi gogo menghasilkan nilai koefisien determinasi $\left(\mathrm{R}^{2}\right)=97.3 \%$ dan $96.7 \%$, sedangkan nilai $\mathrm{R}^{2}$ pada koefisien regresi linier sebesar $96.9 \%$ dan $95.9 \%$. Semakin besar nilai $\mathrm{R}^{2}$ maka model persamaan semakin mampu menerangkan peubah Y (Mattjik dan Sumertajaya, 2006). Untuk $\mathrm{Y}=\mathrm{P}_{40}=60$ (daya berkecambah $60 \%$ ), diperoleh periode pengusangan (X) untuk padi sawah 40 jam dan padi gogo 61 jam. Kurva kuadratik dari MPC fisik dapat dilihat pada Gambar 1.

Penentuan lama penderaan untuk benih padi rawa didasarkan pada persentase daya berkecambah benih varietas Inpara 2. Hal ini dikarenakan persentase daya berkecambah seluruh varietas padi rawa mengalami penurunan yang drastis setelah pengusangan satu hari, kecuali pada benih varietas Inpara 2. Berdasarkan hal tersebut maka waktu pengusangan yang terpilih untuk padi rawa adalah 2 hari, karena varietas Inpara 2 yang telah diusangkan selama 2 hari menunjukkan persentase daya berkecambah yang lebih mendekati $\mathrm{P}_{40}$ yaitu sebesar $59 \%$.

\section{Penentuan Waktu Pengusangan}

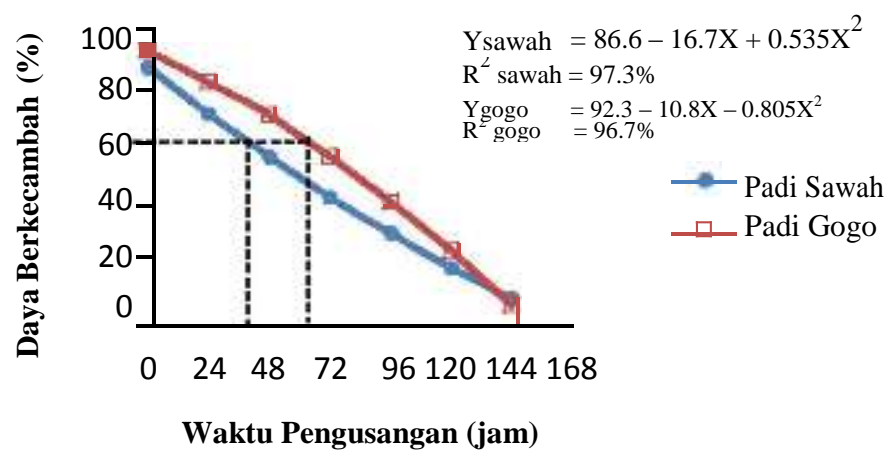

Gambar 1. Kurva Regresi Kuadratik untuk Penentuan Waktu Pengusangan Metode Pengusangan Cepat (MPC) Fisik pada Benih Padi Sawah dan Padi Gogo

Cutrisni, Faiza C. Suwarno dan Suwarno 
Percobaan pendahuluan pengujian $\mathrm{V}_{\mathrm{KT}}{ }^{\text {PEG }}$ hanya dilakukan pada benih padi gogo. Tabel 1 menunjukan bahwa perlakuan pengujian $\mathrm{V}_{\mathrm{KT}}{ }^{\text {PEG }}$ pada tekanan osmotik 0 bar (kontrol) tidak berbeda nyata dengan tekanan osmotic -1.5 bar, tetapi berbeda nyata dengan perlakuan tekanan osmotik -2 bar dan -2.5 bar.

Tabel 1. Daya berkecambah (\%) benih padi gogo pada beberapa taraf tekanan osmotik Polyethylene Glycol (PEG)-6000

\begin{tabular}{cc}
\hline $\begin{array}{c}\text { Tekanan Osmotik } \\
(\text { Bar })\end{array}$ & Daya berkecambah (\%) \\
\hline 0 & $93 \mathrm{a}$ \\
-1.5 & $92 \mathrm{a}$ \\
-2.0 & $75 \mathrm{~b}$ \\
-2.5 & $69 \mathrm{~b}$ \\
\hline
\end{tabular}

Keterangan: Angka pada kolom yang sama dan diikuti huruf yang sama menunjukkan tidak berbeda nyata berdasarkan uji DMRT pada taraf $5 \%$.

Persentase daya berkecambah benih mulai mengalami penurunan yang nyata menjadi $75 \%$ pada tekanan osmotik -2 bar, hal ini menunjukkan bahwa benih sudah mulai menampakkan gejala tercekam. Penelitian sebelumnya menyatakan bahwa penggunaan larutan PEG (BM 6000 atau 8000) untuk menguji perkecambahan padi pada tekanan osmotik -2 dan -12 bar telah dilakukan IRRI dan dapat membedakan varietas yang tahan dan peka terhadap kekeringan (Mc Donald et al. dalam Lestari dan Mariska, 2006).

Pengujian vigor pada kondisi kekeringan selain menggunakan larutan PEG6000 dilakukan juga dengan metode tingkat ketinggian benih $\left(\mathrm{V}_{\mathrm{KT}}{ }^{\text {ketinggian }}{ }^{(\mathrm{PEG})}\right)$. Metode ini menggunakan tiga taraf jumlah kertas stensil daur ulang, yaitu 1-1, 1-2, dan 2-2 lembar per satuan percobaan dengan ketinggian posisi tanam benih 30 $\mathrm{cm}$. Metode $\mathrm{V}_{\mathrm{KT}}$ kekeringan (ketinggian) diuji menggunakan UKD dan diletakkan dengan posisi berdiri pada wadah berisikan air setinggi $3 \mathrm{~cm}$. Data daya berkecambah menunjukkan bahwa jumlah kertas yang digunakan tidak berpengaruh nyata baik pada benih padi sawah maupun padi gogo seperti terlihat pada Tabel 2 .

Persentase daya berkecambah dari semua perlakuan (M1, M2, dan M3) lebih dari $80 \%$ dan secara visual pertumbuhannya tidak menggambarkan adanya gejala cekaman kekeringan. Berdasarkan hasil percobaan tersebut, maka dilakukan pengujian lanjut dengan mengurangi ketinggian air dalam wadah menjadi $2 \mathrm{~cm}$ menggunakan jumlah kertas 1-1 lembar. Pengujian lanjut ini merupakan metode terpilih karena menunjukkan penurunan daya berkecambah yang signifikan sudah mengalami gejala tercekam (Tabel $3)$.

Tabel 2. Pengaruh jumlah kertas (Media) terhadap daya berkecambah metode kekeringan terkontrol pada padi sawah dan padi gogo

\begin{tabular}{ccc}
\hline & & \multicolumn{2}{c}{ Daya Berkecambah (\%) } \\
\cline { 2 - 3 } Perlakuan & Padi Sawah & Padi Gogo \\
\hline M1 & $86.22 \mathrm{a}$ & $86.67 \mathrm{a}$ \\
M2 & $94.22 \mathrm{a}$ & $92.89 \mathrm{a}$ \\
M3 & $88.87 \mathrm{a}$ & $92.89 \mathrm{a}$ \\
\hline
\end{tabular}

Keterangan: Angka pada kolom yang sama dan diikuti huruf yang sama menunjukkan tidak berbeda nyata berdasarkan uji DMRT pada taraf 5\%. Jumlah kertas 1-1 lembar (M1), jumlah kertas 1-2 lembar (M2), dan jumlah kertas 2-2 lembar (M3). 
Tabel 3. Nilai tengah daya berkecambah (\%) benih padi sawah dan padi gogo pada perlakuan $\mathbf{v}_{\mathrm{kt}}^{\text {ketinggian }}$ dengan ketinggian air dalam wadah $3 \mathrm{~cm}$ dan $2 \mathrm{~cm}$

\begin{tabular}{|c|c|c|c|c|c|}
\hline \multirow[b]{2}{*}{ Padi Sawah } & \multicolumn{2}{|c|}{ Ketinggian Air } & \multirow[b]{2}{*}{ Padi Gogo } & \multicolumn{2}{|c|}{ Ketinggian Air } \\
\hline & $3 \mathrm{~cm}$ & $2 \mathrm{~cm}$ & & $3 \mathrm{~cm}$ & $2 \mathrm{~cm}$ \\
\hline Aek Sibundong & 73.33 & 26.67 & Batu Tegi & 84.44 & 62.22 \\
\hline MR-2-3-Si-1-2-1-1 & 84.44 & 22.22 & Jati Luhur & 77.78 & 13.33 \\
\hline B11844-7-17-3 & 93.33 & 46.67 & Inpago 5 & 93.33 & 48.89 \\
\hline BP-1002E-MR-2 & 91.11 & 6.67 & Limboto & 88.89 & 51.11 \\
\hline Ciherang & 88.89 & 11.11 & Situpatenggang & 88.89 & 73.33 \\
\hline Nilai Tengah & $86.22 \mathrm{a}$ & $22.67 \mathrm{~b}$ & Nilai Tengah & $86.67 \mathrm{a}$ & $49.78 b$ \\
\hline
\end{tabular}

Pengujian $\mathrm{V}_{\mathrm{KT}}{ }^{\text {salin(}(\mathrm{NaCl})}$ menggunakan benih padi rawa, menunjukkan bahwa konsentrasi $\mathrm{NaCl}$ 0 ppm (kontrol) tidak berbeda nyata terhadap konsentrasi $\mathrm{NaCl} 3000$ ppm, dan 4000 ppm, sedangkan terhadap konsentrasi 5000 ppm berpengaruh nyata (Tabel 4).

Konsentrasi $\mathrm{NaCl} 4000$ ppm merupakan konsentrasi terpilih pada metode pengujian vigor kekuatan tumbuh pada kondisi salinitas, karena berdasarkan penelitian-penelitian sebelumnya telah banyak menggunakan konsentrasi $\mathrm{NaCl} 4000$ ppm untuk membedakan varietas tahan dan yang peka terhadap cekaman salinitas. Hasil penelitian Fatimah (2010), menyatakan bahwa metode dengan menggunakan kertas tisu towel pada konsentrasi $\mathrm{NaCl} 4000$ ppm dengan cara penanaman uji diatas kertas (UDK) dapat memperlihatkan perbedaan antara genotipe yang toleran dan peka terhadap salinitas.

Tabel 4. Perbandingan konsentrasi nacl terhadap daya berkecambah (\%) benih padi rawa pada kondisi salinitas berbagai konsentrasi $\mathrm{NaCl}$

\begin{tabular}{cc}
\hline Konsentrasi $\mathrm{NaCl}(\mathrm{ppm})$ & Daya Berkecambah $(\%)$ \\
\hline 0 & $88.4 \mathrm{a}$ \\
3000 & $84.4 \mathrm{a}$ \\
4000 & $80.4 \mathrm{ab}$ \\
5000 & $74.8 \mathrm{~b}$ \\
\hline
\end{tabular}

Keterangan: Angka pada kolom yang sama dan diikuti huruf yang sama menunjukkan tidak berbeda nyata berdasarkan uji DMRT pada taraf $5 \%$

\section{Percobaan Utama}

Penelitian ini terdiri dari dua percobaan, yaitu pengujian vigor daya simpan benih melalui MPC secara fisik $\left(\mathrm{V}_{\mathrm{DS}}^{\text {fis }}\right)$, dan pengujian vigor kekuatan tumbuh $\left(\mathrm{V}_{\mathrm{KT}}\right)$ benih pada kondisi suboptimum (cekaman kekeringan dan salinitas).

Pengujian Vigor Daya Simpan $\left(\mathrm{V}_{\mathrm{DS}}\right)$ menggunakan Metode Pengusangan Cepat (MPC) Fisik. Berdasarkan rekapitulasi sidik ragam pada
Tabel 5 menunjukkan bahwa keadaan benih setelah mengalami penderaan beragam. Genotipe berpengaruh sangat nyata terhadap DB tetapi tidak berpengaruh nyata terhadap tolok ukur IV dan BKKN pada benih padi sawah. Genotipe sangat berpengaruh nyata terhadap semua tolok ukur yang diamati pada benih padi gogo, sedangkan pada benih padi rawa genotipe tidak berbeda nyata terhadap semua tolok ukur yang diamati. 
Bul. Agrohorti 3 (3) : 366 - 376 (2015)

Tabel 5. Rekapitulasi F-Hitung pengaruh genotipe padi setelah diusangkan terhadap tolok ukur yang diamati

\begin{tabular}{llcccl}
\hline \multirow{2}{*}{ Kelompok } & Sumber & \multirow{2}{*}{ Derajat bebas } & \multicolumn{3}{c}{ F-Hitung } \\
\cline { 4 - 6 } & keragaman & & DB $(\%)$ & IV $(\%)$ & BKKN $(\mathrm{g})$ \\
\hline Padi & Ulangan & 2 & $0.74^{\text {th }}$ & $0.26^{\text {th }}$ & $0.28^{*}$ \\
Sawah & Perlakuan & 19 & $3.69^{* *}$ & $1.10^{* *}$ & $1.85^{* *}$ \\
\multirow{2}{*}{ Padi Gogo } & Ulangan & 2 & $2.28^{\text {th }}$ & $2.12^{\text {th }}$ & $5.26^{\text {tn }}$ \\
& Perlakuan & 19 & $8.55^{* *}$ & $3.46^{\text {tn }}$ & $4.54^{\text {tn }}$ \\
Padi Rawa & Ulangan & 2 & $10.72^{* *}$ & $4.2^{*}$ & $5.55^{* *}$ \\
\hline
\end{tabular}

Keterangan : ${ }^{* *}=$ sangat nyata, ${ }^{*}=$ nyata, $\mathrm{tn}=$ tidak berbedanyata, $\mathrm{DB}=$ daya berkecambah, $\mathrm{IV}=$ indeks vigor, $\mathrm{BKKN}=$ berat kering kecambah normal

Genotipe tertinggi padi sawah dan padi gogo yang diduga memiliki $\mathrm{V}_{\mathrm{DS}}$ yang tinggi, yaitu genotipe B12539-7-SI-1-1-MR-2-PN-3-1 dan B12154D-MR-22-8 dengan persentase nilai tengah daya berkecambah $\geq 60 \%$. Semua genotipe padi rawa diduga memiliki $\mathrm{V}_{\mathrm{DS}}$ rendah karena nilai tengah daya berkecambahnya $\leq 60 \%$, nilai terbesar hanya $57.33 \%$ pada genotipe B13109-5-MR-3-KA1. Hal ini dapat disebabkan oleh faktor 4enetic atau innate factor, induced factor yaitu faktor lapang mulai benih ditanam sampai siap simpan, factor enforced atau kondisi penyimpanan.

Pengujian Vigor Kekuatan Tumbuh ( $\mathrm{V}_{\mathrm{KT}}$ ) pada Kondisi Sub-optimum.

a. Pengujian Vigor Kekuatan Tumbuh $\left(\mathrm{V}_{\mathrm{KT}}\right)$ pada

Kondisi Sub-optimum Kekeringan
Hasil rekapitulasi sidik ragam pada Tabel 6 menunjukkan secara keseluruhan tolok ukur daya berkecambah berpengaruh sangat nyata terhadap genotipe padi sawah dan gogo baik pada metode $\mathrm{V}_{\mathrm{KT}}$ kekeringan(PEG) maupun $\mathrm{V}_{\mathrm{KT}}{ }^{\text {kekeringan(ketinggian) }}$. Perlakuan $\mathrm{V}_{\mathrm{KT}}{ }^{\mathrm{PEG}}$ pada padi sawah, genotip berpengaruh sangat nyata terhadap tolok ukur DB, IV, dan BKKN serta berpengaruh nyata terhadap $\mathrm{PP}$, tetapi genotip tidak berpengaruh nyata terhadap PK dan PA. Berbeda dengan perlakuan $\mathrm{V}_{\mathrm{KT}}$ kekeringan(ketinggian) pada padi sawah, genotip berpengaruh sangat nyata terhadap PA, dan berpengaruh nyata terhadap $\mathrm{DB}$ dan $\mathrm{PK}$, serta genotip tidak berpengaruh nyata terhadap BKKN dan PP.

Tabel 6. Rekapitulasi pengujian $\mathrm{v}_{\mathrm{kt}}$ pada kondisi sub-optimum kekeringan dengan metode $\mathrm{v}_{\mathrm{kt}}^{\text {kekeringan(peg) }}$ dan $\mathrm{V}_{\mathrm{kt}}^{\text {kekeringan(ketinggian) }}$

\begin{tabular}{|c|c|c|c|c|}
\hline \multirow{3}{*}{ Tolok Ukur } & \multicolumn{4}{|c|}{ Perlakuan } \\
\hline & \multicolumn{2}{|c|}{ PEG-6000 -2 Bar } & \multicolumn{2}{|c|}{ Tingkat Kekeringan } \\
\hline & Padi Sawah & Padi Gogo & Padi Sawah & Padi Gogo \\
\hline $\mathrm{DB}(\%)$ & $* *$ & $* *$ & $*$ & $*$ \\
\hline IV (\%) & ** & tn & $(-)$ & $(-)$ \\
\hline BKKN (g) & ** & ** & tn & * \\
\hline PK $(\mathrm{cm})$ & tn & $*$ & $*$ & * \\
\hline PP $(\mathrm{cm})$ & * & tn & tn & tn \\
\hline PA $(\mathrm{cm})$ & tn & $*$ & $* *$ & $* *$ \\
\hline
\end{tabular}

Keterangan: $* *=$ sangat nyata, $*=$ nyata, $\mathrm{tn}=$ tidak nyata, $(-)=$ tidak diuji

Perlakuan $\mathrm{V}_{\mathrm{KT}}^{\text {kekeringan (PEG) }}$ pada benih padi gogo, genotipe berpengaruh sangat nyata terhadap $\mathrm{DB}$, dan BKKN, dan berpengaruh nyata terhadap PK, dan PA, tetapi genotipe tidak berpengaruh nyata pada tolok ukur IV dan PP. Berbeda dengan perlakuan $\mathrm{V}_{\mathrm{KT}}$ kekeringan(ketinggian), genotip berpengaruh sangat nyata terhadap PA dan berpengaruh nyata terhadap tolok ukur DB, BKKN, dan PK, tetapi tidak berpengaruh nyata terhadap PP. Pengujian $V_{K T}$ pada kondisi sub-optimum kekeringan dapat menggunakan metode $\mathrm{V}_{\mathrm{KT}}$ kekeringan(PEG) dan $\mathrm{V}_{\mathrm{KT}}$ kekeringan(ketinggian) $u n t u k$ mengetahui genotip yang toleran terhadap cekaman kekeringan $\mathrm{V}_{\mathrm{KT}}$ kekeringan(ketinggian) lebih mudah dan cepat dalam aplikasi serta secara ekonomis lebih murah digunakan dibandingkan pengujian $\mathrm{V}_{\mathrm{KT}}{ }^{\mathrm{PEG}}$.

Pengujian Vigor Kekuatan Tumbuh $\left(\mathrm{V}_{\mathrm{KT}}\right)$ pada Kondisi Sub-optimum Salinitas. Tabel 7 menunjukkan bahwa perlakuan $\mathrm{V}_{\mathrm{DS}}^{\text {salin }}{ }^{(\mathrm{NaCl})}$ pada padi rawa, genotip berpengaruh sangat nyata terhadap IV dan BKKn, serta berpengaruh nyata terhadap DB dan PP, tetapi tidak berpengaruh nyata terhadap PK dan PA. 
Bul. Agrohorti 3 (3) : 366 - 376 (2015)

Tabel 7. Rekapitulasi pengujian vigor kekuatan tumbuh $\left(\mathrm{v}_{\mathrm{kt}}\right)$ pada kondisi salin dengan konsentrasi $\mathrm{NaCl} 4000$ ppm

\begin{tabular}{|c|c|c|c|c|c|c|c|}
\hline \multirow[b]{2}{*}{$\begin{array}{c}\text { Sumber } \\
\text { Keragaman }\end{array}$} & \multirow[b]{2}{*}{$\begin{array}{l}\text { Derajat } \\
\text { Bebas }\end{array}$} & \multicolumn{6}{|c|}{ F-Hit } \\
\hline & & $\begin{array}{l}\text { DB } \\
(\%)\end{array}$ & $\begin{array}{l}\text { IV } \\
(\%)\end{array}$ & $\begin{array}{c}\text { BKKN } \\
(\mathrm{g})\end{array}$ & $\begin{array}{l}\text { PK } \\
(\mathrm{cm})\end{array}$ & $\begin{array}{l}\mathrm{PP} \\
(\mathrm{cm})\end{array}$ & $\begin{array}{r}\text { PA } \\
(\mathrm{cm})\end{array}$ \\
\hline Ulangan & 2 & $* *$ & $* *$ & tn & $* *$ & ** & $*$ \\
\hline Perlakuan & 19 & * & $* *$ & $* *$ & tn & $*$ & tn \\
\hline
\end{tabular}

Persentase DB tertinggi senilai $89.33 \%$ pada genotipe awa B13120-19-MR-2-KA-1 dan nilai terendah sebesar $54.67 \%$ pada genotipe B13100-3-MR-1-KA-2.

Korelasi antara Vigor Daya Simpan $\left(\mathrm{V}_{\mathrm{DS}}\right)$ dengan Vigor Kekuatan Tumbuh $\left(\mathrm{V}_{\mathrm{KT}}\right)$. Tabel 8 menunjukkan bahwa sebagian besar tolok ukur $\mathrm{V}_{\mathrm{DS}}$ tidak berkorelasi dengan $\mathrm{V}_{\mathrm{KT}}{ }^{\text {kekeringan }}$ (PEG) dan

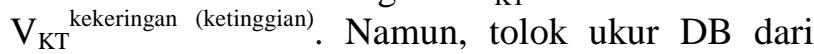

pengujian $V_{D S}$ metode pengusangan cepat fisik berkorelasi negatif dan sangat nyata terhadap tolok ukur DB, IV, dan BKKN pada pengujian $\mathrm{V}_{\mathrm{KT}}$ kekeringan (PEG) pada genotipe padi sawah. BKKN dari pengujian $V_{D S}$ berkolerasi negatif dan sangat nyata terhadap tolok ukur DB dan BKKN, serta berkorelasi negatif dan nyata terhadap IV pada pengujian $\mathrm{V}_{\mathrm{KT}}$ kekeringan (PEG) padi sawah.

Tabel 8. Koefisien korelasi antara tolok ukur vigor daya simpan $\left(\mathrm{v}_{\mathrm{ds}}\right)$ dengan tolok ukur vigor kekuatan tumbuh $\left(\mathrm{v}_{\mathrm{kt}}\right)$ untuk benih padi sawah dan padi gogo

\begin{tabular}{|c|c|c|c|c|c|c|}
\hline \multirow{3}{*}{$\begin{array}{c}\text { Tolok Ukur } \\
\mathrm{V}_{\mathrm{KT}}\end{array}$} & \multicolumn{6}{|c|}{ Tolok Ukur $\mathrm{V}_{\mathrm{DS}}$} \\
\hline & \multicolumn{3}{|c|}{ Padi Sawah } & \multicolumn{3}{|c|}{ Padi Gogo } \\
\hline & DB (\%) & IV (\%) & $\mathrm{BKKN}(\mathrm{g})$ & DB (\%) & IV $(\%)$ & BKKN (g) \\
\hline \multicolumn{7}{|c|}{$\mathrm{V}_{\mathrm{KT}}{ }^{\text {kekeringan (PEG) }}$} \\
\hline DB (\%) & $-0.719^{* *}$ & $-0.446 *$ & $-0.611^{* *}$ & $-0.083^{\mathrm{tn}}$ & $0.185^{\text {tn }}$ & $0.145^{\mathrm{tn}}$ \\
\hline IV $(\%)$ & $-0.501^{* *}$ & $-0.269^{\mathrm{tn}}$ & $-0.399^{*}$ & $-0.086^{\mathrm{tn}}$ & $0.078^{\mathrm{tn}}$ & $0.138^{\text {tn }}$ \\
\hline $\mathrm{BKKN}(\mathrm{g})$ & $-0.641^{* *}$ & $-0.308^{\text {th }}$ & $-0.520^{* *}$ & $-0.041^{\text {tn }}$ & $-0.016^{\mathrm{tn}}$ & $0.081^{\text {tn }}$ \\
\hline $\mathrm{PK}(\mathrm{cm})$ & $-0.213^{\mathrm{tn}}$ & $-0.189^{\mathrm{tn}}$ & $-0.149^{\mathrm{tn}}$ & $-0.083^{\text {tn }}$ & $-0.183^{\mathrm{tn}}$ & $-0.245^{\mathrm{tn}}$ \\
\hline $\mathrm{PP}(\mathrm{cm})$ & $-0.184^{\mathrm{tn}}$ & $-0.020^{\text {tn }}$ & $-0.098^{\mathrm{tn}}$ & $0.096^{\mathrm{tn}}$ & $0.003^{\text {tn }}$ & $-0.051^{\text {th }}$ \\
\hline $\mathrm{PA}(\mathrm{cm})$ & $-0.184^{\mathrm{tn}}$ & $-0.098^{\mathrm{tn}}$ & $-0.144^{\mathrm{tn}}$ & $-0.146^{\mathrm{tn}}$ & $-0.216^{\mathrm{tn}}$ & $-0.262^{\mathrm{tn}}$ \\
\hline \multicolumn{7}{|c|}{$\mathrm{V}_{\mathrm{KT}}{ }^{\text {kekeringan (ketinggian) }}$} \\
\hline $\mathrm{DB}(\%)$ & $0.166^{\mathrm{tn}}$ & $0.468^{\mathrm{tn}}$ & $0.036^{\mathrm{tn}}$ & $-0.076^{\mathrm{tn}}$ & $-0.071^{* *}$ & $-0.060^{* *}$ \\
\hline $\mathrm{BKKN}(\mathrm{g})$ & $0.328^{\mathrm{tn}}$ & $0.390^{\mathrm{tn}}$ & $0.447^{\mathrm{tn}}$ & $0.132 *$ & $0.083^{* *}$ & $0.118^{* *}$ \\
\hline $\mathrm{PK}(\mathrm{cm})$ & $-0.157^{\mathrm{tn}}$ & $-0.067^{\text {tn }}$ & $-0.166^{\mathrm{tn}}$ & $-0.091^{\text {th }}$ & $0.029^{\mathrm{tn}}$ & $-0.073^{\mathrm{tn}}$ \\
\hline $\mathrm{PP}(\mathrm{cm})$ & $0.096^{\mathrm{tn}}$ & $0.235^{\mathrm{tn}}$ & $0.172^{\text {tn }}$ & $-0.286^{\mathrm{tn}}$ & $-0.173^{\mathrm{tn}}$ & $0.030^{\mathrm{tn}}$ \\
\hline $\mathrm{PA}(\mathrm{cm})$ & $-0.195^{\mathrm{tn}}$ & $-0.130^{\mathrm{tn}}$ & $-0.226^{\mathrm{tn}}$ & $0.011^{\text {tn }}$ & $0.101^{\text {tn }}$ & $0.039^{\mathrm{tn}}$ \\
\hline
\end{tabular}

Keterangan: $* *=$ sangat nyata, $*=$ nyata, $\mathrm{tn}=$ tidak nyata.

Tolok ukur IV dan berat BKKN pada pengujian $V_{D S}$ berkolerasi negatif dan sangat nyata terhadap daya berkecambah $\mathrm{V}_{\mathrm{KT}}$ kekeringan (ketinggian) pada padi gogo. IV dan BKKN pada pengujian $V_{D S}$ berkolerasi positif dan sangat nyata serta $D B V_{D S}$ berkolerasi positif dan nyata terhadap DB $\mathrm{V}_{\mathrm{KT}}{ }^{\text {kekeringan (ketinggian) }}$ pada padi gogo. Hipotesis awal menduga adanya korelasi positif antara $\mathrm{V}_{\mathrm{DS}}$ dengan $\mathrm{V}_{\mathrm{KT}}{ }^{\text {kekeringan (PEG) }}$ dan $\mathrm{V}_{\mathrm{KT}}{ }^{\text {kekeringan (ketinggian) }}$, tetapi hasil penelitian menunjukkan secara umum korelasi yang terjadi negatif dan tidak nyata sehingga diperlukan adanya pengujian lanjut.

Tabel 9 secara umum memberikan informasi bahwa tolok ukur $\mathrm{V}_{\mathrm{DS}}$ dengan tolok ukur $\mathrm{V}_{\mathrm{KT}}$ salin (NaCl) semuanya tidak nyata. Hasil dari analisis korelasi pengujian $\mathrm{V}_{\mathrm{DS}}$, terhadap tolok ukur yang diamati pada pengujian $\mathrm{V}_{\mathrm{KT}}$ sebagian besar tidak menunjukkan adanya hubungan erat antara kedua tolok ukur. Berdasarkan hal tersebut maka dilakukan pengujian lanjut dengan cara mengurutkan nilai DB genotipe padi yang diamati pada pengujian $V_{D S}$ dari nilai terbesar sampai terkecil dengan tolok ukur pada pengujian $\mathrm{V}_{\mathrm{KT}}$. 
Bul. Agrohorti 3 (3) : 366 - 376 (2015)

Tabel 9. Koefisien korelasi antara tolok ukur vigor daya simpan $\left(\mathrm{v}_{\mathrm{ds}}\right)$ dengan tolok ukur pada $\mathrm{v}_{\mathrm{kt}}^{\text {salin (nacl) }}$ padi rawa

\begin{tabular}{|c|c|c|c|}
\hline \multirow{2}{*}{ Tolok Ukur $\mathrm{V}_{\mathrm{KT}}^{\text {salin }(\mathrm{NaCl})}$} & \multicolumn{3}{|c|}{ Tolok Ukur $\mathrm{V}_{\mathrm{DS}}$} \\
\hline & DB $(\%)$ & IV $(\%)$ & $\mathrm{BKKN}(\mathrm{g})$ \\
\hline DB (\%) & $0.091^{\text {tn }}$ & $0.178^{\text {tn }}$ & $0.048^{\text {tn }}$ \\
\hline IV (\%) & $0.138^{\text {tn }}$ & $0.096^{\mathrm{tn}}$ & $0.232^{\mathrm{tn}}$ \\
\hline BKKN (g) & $0.139^{\text {tn }}$ & $-0.072^{\mathrm{tn}}$ & $-0.135^{\text {tn }}$ \\
\hline $\mathrm{PK}(\mathrm{cm})$ & $0.159^{\text {tn }}$ & $0.115^{\mathrm{tn}}$ & $0.190^{\mathrm{tn}}$ \\
\hline $\mathrm{PP}(\mathrm{cm})$ & $0.162^{\text {tn }}$ & $0.129^{\text {tn }}$ & $0.237^{\text {tn }}$ \\
\hline $\mathrm{PA}(\mathrm{cm})$ & $0.159^{\text {tn }}$ & $0.115^{\text {tn }}$ & $0.190^{\text {tn }}$ \\
\hline
\end{tabular}

Keterangan: $\mathrm{tn}=$ tidak nyata

Tabel 10 menunjukkan lima genotipe terbesar benih padi sawah dan padi gogo pada perlakuan $\mathrm{V}_{\mathrm{KT}}$ kekeringan (PEG) berdasarkan DB pada pengujian $\mathrm{V}_{\mathrm{DS}}$. Lima genotipe terbesar benih padi sawah dan padi gogo, secara keseluruhan menunjukan tidak adanya hubungan antara $V_{D S}$ dengan $\mathrm{V}_{\mathrm{KT}}$.

Tabel 10. Lima genotipe padi sawah dan padi gogo dengan daya berkecambah terbesar pada pengujian $\mathrm{v}_{\mathrm{ds}}$ dan tolok ukur lainnya pada pengujian $\mathrm{v}_{\mathrm{kt}}$ kekeringan (peg)

\begin{tabular}{|c|c|c|c|c|c|c|c|}
\hline \multirow{2}{*}{ Genotipe } & $\mathrm{V}_{\mathrm{DS}}$ & \multicolumn{6}{|c|}{ Tolok Ukur $\mathrm{V}_{\mathrm{KT}}{ }^{\text {kekeringan (PEG) }}$} \\
\hline & DB (\%) & DB (\%) & IV (\%) & $\mathrm{BKKN}(\mathrm{g})$ & PK $(\mathrm{cm})$ & $\mathrm{PP}(\mathrm{cm})$ & PA $(\mathrm{cm})$ \\
\hline \multicolumn{8}{|c|}{ Padi Sawah } \\
\hline $\begin{array}{l}\text { B12539-7-SI-1-1- MR-2- } \\
\text { PN-3-1 }\end{array}$ & 82.7 & 17.33 & 0.00 & 0.01 & 11.6 & 3.3 & 8.3 \\
\hline B12653-MR-8-2-PN-3-1 & 81.3 & 5.33 & 0.00 & 0.01 & 11.5 & 3.0 & 8.5 \\
\hline $\begin{array}{l}\text { B11742-RS*2-4-MR-16-3- } \\
\text { 2-SI-4-4-MR-3- PN-2-4 }\end{array}$ & 73.3 & 32 & 6.67 & 0.04 & 13.5 & 3.3 & 10.2 \\
\hline $\begin{array}{l}\text { B12512-18-SI-2-2- MR-3- } \\
\text { PN-3-2 }\end{array}$ & 68 & 32 & 0.00 & 0.04 & 11.5 & 3.6 & 8.9 \\
\hline B12653-MR-8-2-PN-2-3 & 62.7 & 25.3 & 0.00 & 0.02 & 11.8 & 3.2 & 8.6 \\
\hline \multicolumn{8}{|c|}{ Padi Gogo } \\
\hline B12154D-MR-22-8 & 82.7 & 62.7 & 2.67 & 0.06 & 12.1 & 3.3 & 8.7 \\
\hline B12165D-MR-8-1 & 80.0 & 37.3 & 0.00 & 0.04 & 11.1 & 3.1 & 8.0 \\
\hline B12492C-MR-21-2-5 & 73.3 & 1.33 & 0.00 & 0.00 & 12.0 & 2.5 & 9.5 \\
\hline B12492C-MR-21-2-4 & 70.7 & 1.33 & 0.00 & 0.00 & 12.3 & 2.8 & 9.5 \\
\hline B11604E-TB-2-4-1-5 & 66.7 & 24.0 & 0.00 & 0.03 & 11.2 & 3.1 & 8.17 \\
\hline
\end{tabular}

Genotipe benih padi sawah B11742-RS*24-MR-16-3-2-SI-4-4-MR-3-PN-2-4 dan B12512-18SI-2-2-MR-3-PN-3-2 menunjukkan memiliki $\mathrm{V}_{\mathrm{DS}}$ dan $\mathrm{V}_{\mathrm{KT}}$ yang tinggi karena secara umum semua nilai tolok ukur yang diamati merupakan hasil terbesar dibandingkan genotipe lainnya, kecuali pada tolok ukur PP, PK dan PA. Genotipe benih padi gogo B12154D-MR-22-8 memiliki respon $V_{D S}$ dan $\mathrm{V}_{\mathrm{KT}}$ pada kondisi kekeringan yang tinggi, karena semua tolok ukur yang diamati termasuk genotipe yang memiliki nilai lima terbesar.

Berdasarkan Tabel 11 secara umum menunjukkan bahwa tidak ada hubungan $V_{D S}$ dan $\mathrm{V}_{\mathrm{KT}}$ dari perbandingan lima genotipe terbesar benih padi sawah dan padi gogo pada perlakuan tingkat kekeringan berdasarkan daya berkecambah pada pengujian $\mathrm{V}_{\mathrm{DS}}$. 
Bul. Agrohorti 3 (3) : 366 - 376 (2015)

Tabel 11. Lima genotipe padi sawah dan padi gogo dengan daya berkecambah terbesar pada pengujian $\mathrm{v}_{\mathrm{ds}}$ dan tolok ukur lainnya pada pengujian $\mathrm{v}_{\mathrm{kt}}{ }^{\text {kekeringan (ketinggian) }}$

\begin{tabular}{|c|c|c|c|c|c|c|}
\hline \multirow{2}{*}{ Genotipe } & $\mathrm{V}_{\mathrm{DS}}$ & \multicolumn{5}{|c|}{ Tolok Ukur $\mathrm{V}_{\mathrm{KT}}{ }^{\text {kekeringan (ketinggian) }}$} \\
\hline & DB (\%) & $\mathrm{DB}(\%)$ & $\mathrm{BKKN}(\mathrm{g})$ & PK $(\mathrm{cm})$ & PP $(\mathrm{cm})$ & PA $(\mathrm{cm})$ \\
\hline \multicolumn{7}{|c|}{ Padi Sawah } \\
\hline B12539-7-SI-1-1- MR-2-PN-3-1 & 82.7 & 26.7 & 0.01 & 13.7 & 3.6 & 10.1 \\
\hline B12653-MR-8-2-PN-3-1 & 81.3 & 57.8 & 0.05 & 13.2 & 3.4 & 9.9 \\
\hline $\begin{array}{l}\text { B11742-RS*2-4-MR-16-3-2-SI-4-4-MR- } \\
\text { 3- PN-2-4 }\end{array}$ & 73.3 & 20.0 & 0.00 & 13.3 & 3.1 & 10.2 \\
\hline B12512-18-SI-2-2- MR-3-PN-3-2 & 68.0 & 46.7 & 0.03 & 11.6 & 3.4 & 8.3 \\
\hline B12653-MR-8-2-PN-2-3 & 62.7 & 35.6 & 0.01 & 12.9 & 3.6 & 9.4 \\
\hline \multicolumn{7}{|c|}{ Padi Gogo } \\
\hline B12154D-MR-22-8 & 82.7 & 44.5 & 0.02 & 13.9 & 3.3 & 10.6 \\
\hline B12165D-MR-8-1 & 80.0 & 35.6 & 0.01 & 11.3 & 3.0 & 8.3 \\
\hline B12492C-MR-21-2-5 & 73.3 & 4.5 & 0.00 & 13.2 & 2.75 & 10.4 \\
\hline B12492C-MR-21-2-4 & 70.7 & 2.2 & 0.00 & 13.0 & 2.5 & 10.5 \\
\hline B11604E-TB-2-4-1-5 & 66.7 & 17.8 & 0.01 & 13.6 & 3.2 & 10.4 \\
\hline
\end{tabular}

Genotipe benih padi sawah B12653-MR-82-PN-3-1 menunjukkan memiliki $\mathrm{V}_{\mathrm{DS}}$ dan $\mathrm{V}_{\mathrm{KT}}$ yang tinggi karena semua nilai tolok ukur yang diamati merupakan hasil terbesar dibandingkan genotipe lainnya, kecuali pada tolok ukur panjang plumula. Genotipe benih padi gogo B12154D-MR-22-8 memiliki hubungan antara $\mathrm{V}_{\mathrm{DS}}$ dan $\mathrm{V}_{\mathrm{KT}}$ pada kondisi kekeringan, karena semua tolok ukur yang diamati termasuk genotipe yang memiliki nilai lima terbesar kecuali pada tolok ukur panjang kecambah dan panjang akar.

Tabel 12 menunjukkan dari lima genotipe benih padi rawa hanya satu yang diduga memiliki hubungan erat antara $\mathrm{V}_{\mathrm{DS}}$ dengan $\mathrm{V}_{\mathrm{KT}}$, yaitu pada genotipe B13120-19-MR-2-KA-1. Semua nilai tolok ukur pada genotipe ini merupakan nilai terbesar dibandingkan genotipe lainnya kecuali pada tolok ukur berat kering kecambah normal.

Tabel 12. Lima genotipe padi rawa dengan daya berkecambah terbesar pada pengujian $\mathrm{v}_{\mathrm{ds}}$ dan tolok ukur lainnya pada pengujian $\mathrm{V}_{\mathrm{kt}}^{\text {salin (nacl) }}$

\begin{tabular}{lcccccc}
\hline \multirow{2}{*}{\multicolumn{1}{c}{ Genotipe }} & \multicolumn{5}{c}{$\mathrm{V}_{\mathrm{DS}}$} & \multicolumn{5}{c}{ Tolok Ukur $\mathrm{V}_{\mathrm{KT}}^{\text {salin (NaCl) }}$} \\
\cline { 2 - 7 } & $\mathrm{DB}(\%)$ & $\mathrm{DB}(\%)$ & $\mathrm{BKKN}(\mathrm{g})$ & $\mathrm{PK}(\mathrm{cm})$ & $\mathrm{PP}(\mathrm{cm})$ & PA $(\mathrm{cm})$ \\
\hline B13109-5-MR-3-KA-1 & 57.33 & 77.33 & 8.00 & 0.09 & 12.8 & 4.2 \\
B13120-19-MR-2-KA-1 & 44.00 & 86.67 & 28.00 & 0.08 & 14.3 & 4.93 \\
B13100-3-MR-1-KA-2 & 41.33 & 54.67 & 4.00 & 0.09 & 12.9 & 3.8 \\
B13109-5-MR-KA-2 & 37.33 & 77.33 & 12.00 & 0.09 & 13.0 & 4.8 \\
B13100-2-MR-1-KA-2 & 37.33 & 78.67 & 16.00 & 0.08 & 13.1 & 4.7 \\
\hline
\end{tabular}

Pengujian $\mathrm{V}_{\mathrm{KT}}^{\text {salin }(\mathrm{NaCl})}$ dengan konsentrasi $\mathrm{NaCl} 4000$ ppm menunjukkan bahwa tidak ada hubungan $\mathrm{V}_{\mathrm{DS}}$ dan $\mathrm{V}_{\mathrm{KT}}{ }^{\text {salin }(\mathrm{NaCl})}$ dari perbandingan

\section{KESIMPULAN}

Waktu pengusangan dalam pengujian vigor daya simpan $\left(\mathrm{V}_{\mathrm{DS}}\right)$ benih dengan metode pengusangan cepat fisik pada genotipe padi sawah, padi gogo, dan padi rawa adalah 40 jam, 61 jam, dan 48 jam. Pengujian vigor kekuatan tumbuh $\left(\mathrm{V}_{\mathrm{KT}}\right)$ pada kondisi kekeringan benih padi sawah dan padi gogo dapat digunakan dengan perlakuan $\mathrm{V}_{\mathrm{KT}}$ kekeringan(PEG) dan $\mathrm{V}_{\mathrm{KT}}$ kekeringan (ketinggian). Diantara kedua metode tersebut, metode $\mathrm{V}_{\mathrm{KT}}$ kekeringan (ketinggian) lebih mudah dan cepat dalam aplikasi serta secara lima genotipe terbesar benih padi rawa berdasarkan daya berkecambah pada pengujian $\mathrm{V}_{\mathrm{DS}}$.

ekonomis lebih murah dibandingkan metode $\mathrm{V}_{\mathrm{KT}}{ }^{\text {kekeringan (PEG) }}$. Metode $\mathrm{V}_{\mathrm{KT}}{ }^{\text {kekeringan (ketinggian) }}$ yang dapat digunakan adalah jumlah media kertas stensil daur ulang 1-1 lembar dengan ketinggian posisi tanam benih $30 \mathrm{~cm}$ dari permukaan air. Metode pengecambahan yang digunakan Uji Kertas Digulung (UKD) dan diletakkan dengan posisi vertikal pada wadah berisikan air setinggi $2 \mathrm{~cm}$ yang dijaga konstan. Konsentrasi $\mathrm{NaCl}$ dalam pengujian $\mathrm{V}_{\mathrm{KT}}$ salin $(\mathrm{NaCl})$ pada genotipe padi rawa menggunakan $\mathrm{NaCl} 4000$ ppm.

Secara keseluruhan tidak ada korelasi antara $\mathrm{V}_{\mathrm{DS}}$ dan $\mathrm{V}_{\mathrm{KT}}$. Hasil uji lanjut tentang 
kesamaan lima genotipe yang memiliki nilai $\mathrm{V}_{\mathrm{DS}}$ tertinggi dan nilai $\mathrm{V}_{\mathrm{KT}}$ yang dihasilkan, menunjukkan bahwa tidak ada kesamaan antara keduanya. Genotipe dengan $\mathrm{V}_{\mathrm{DS}}$ tertinggi berturutturut untuk padi sawah, padi gogo, dan padi rawa adalah B12539-7-SI-1-1-MR-2-PN-3-1, B12154DMR-22-8, dan B13109-5-MR-3-KA-1. Genotipe dengan $\mathrm{V}_{\mathrm{KT}}$ kekeringan (PEG) dan $\mathrm{V}_{\mathrm{KT}}$ kekeringan (ketinggan) tertinggi adalah Sintanur dan B12653- MR-8-2PN-3-1 pada padi sawah, B12154D-MR-22-8 pada padi gogo, sedangkan genotipe tertinggi $\mathrm{V}_{\mathrm{KT}}$ salin (NaCl) pada padi rawa adalah B13120-19-MR-2-KA1.

\section{DAFTAR PUSTAKA}

Fatimah, S. 2010. Pengujian Toleransi Genotipe Padi (Oryza sativa L.) terhadap Salinitas pada Fase Perkecambahan. [skripsi]. Bogor (ID) : Institut Pertanian Bogor.

Gomez, K.A., Gomez, A.A. 1995. Prosedur Statistik untuk Penelitian Pertanian (diterjemahkan dari : Statistical Prosedures for Agricultural
Research, penerjemah : E. Sjamsuddin dan J.S. Baharsjah). Jakarta (ID) : Universitas Indonesia

Mattjik, A.A., Sumertajaya, I.M. 2006. Perancangan Percobaan dengan Aplikasi SAS dan Minitab. Jilid 1. Bogor (ID) : IPB Press.

Lestari, E.G., Mariska, I. 2006. Identifikasi somaklon padi Gajahmungkur, Towuti dan IR 64 tahan kekeringan menggunakan Polyethelene Glycol. Bul. Agron. 34(2):71-78.

Sadjad, S. 1994. Kuantifikasi Metabolisme Benih. Jakarta (ID) : PT Gramedia Widiasarana Indonesia.

Sadjad, S., Murniati, E., Satriyas, I. 1999. Parameter Pengujian Vigor Benih dari Komparatif ke Simulatif. Jakarta (ID) : PT Gramedia Widiasarana Indonesia.

Sutopo, L. 2004. Teknologi Benih. (Revisi ke-6). Jakarta (ID) : PT Raja Grafindo Persada. 